\title{
Assessment of the Assistance of Agricultural Development Programme (ADP) On Poultry Production in Ndokwa West, Local Government Area, Delta State, Nigeria
}

\author{
Tibi, K.N ${ }^{1^{*}}$ and Oyem, A. $\mathbf{A}^{1}$ \\ ${ }^{1}$ Delta State Polytechnic, Ozoro, Delta State, Nigeria \\ *Correspndent Author Email: tkentus@gmail.com
}

\begin{abstract}
The study was carried out to assess the extent of assistance of Agricultural Development Programme (ADP) on Poultry Production in Ndokwa West Local Government Area, Delta State. A simple random sampling technique was employed in the selection of six (6) villages from the study area, ten (10) poultry farmers were randomly selected from each of the six villages giving a total sample size of sixty (60). Data was collected with structured questionnaire administered to the respondents in the study area. Data was analyzed with descriptive statistics such as frequency, mean and percentages. The result of the demographic characteristics of the poultry farmers showed that the mean age of the respondents was 50.5 years. The study also showed that $46 \%$ of the respondents had formal education while $54 \%$ of the respondent had no formal education. The respondents' gender was $90 \%$ males and $10 \%$ females. The intensive system of poultry production was higher $(67 \%)$ than the semi-intensive $(25 \%)$ and extensive system (8\%). The study further showed that the source of credit facilities to poultry farmers were personal savings (36.7\%), ADP (30\%) banks (8\%), cooperative (13.3\%). The study also showed that only few of the farmers received assistance from ADP in the form of training on improved agricultural technology (33.3\%), credit and inputs provision for poultry farmers (16.7\%). About $20 \%$ of the respondents are engaged in broilers production, $30 \%$ in layers production while $50 \%$ are in both layers and broilers production. However, it was observed that in spite of these assistance of ADP on poultry production, the living standard of majority of the poultry farmers in the study area has not improved. Therefore, the following recommendations are made; ADP should create more sensitization programmes so that more poultry farmers will benefit. More credits and inputs on poultry production should be made available so that more poultry farmers can access the facilities.
\end{abstract}

Key words: Agricultural Development Programme, Assistance of Poultry farmers, Production Development Programme

DOI: 10.7176/ijcab.v3iII.13, urn:nbn:de:0000ijcab.v3iII.133

Cite this Article:

Tibi, K., \& Oyem, A. (2019). Assessment of Agricultural Development Programme (ADP) Assistance on Poultry Production in Ndokwa West Local Government Area, Delta State, Nigeria. International Journal of Current Aspects, 3(II), 212-217. http://journals.ijcab.org/journals/index.php/ijcab/article/view/13

\section{INTRODUCTION}

Agricultural development programme (ADP) came into existence in Nigeria during the third National Development plan in 1980 to improve Agriculture and food production. Agricultural Development Programme is a World bank assisted project, consisting of an input delivery and credit system (Oladejo, Olawuyi, and Anjorin,, 2011). In 1986 ADP was established in the defunct Bendel State with emphasis on extension through training and visitation. But with the creation of Delta State the Delta Agricultural Development Programme centers on rural 
development programmes in the field of agricultural facilities, the development of rural farming families, thereby raising standard of living (Delta Delta State Ministry of Agriculture and Natural Resources, 2011). According to Okowea (2007) the schemes include loan disbursement to farmers, distribution of poultry input to poultry farmers and provision of extension packages for teaching farmers, supervising farmers and motivating farmers' interest for result oriented and teaching to increased poultry production as well as income generation characterized by minimal risk. Poultry production occupies a prominent position in providing annual protein as it account for $25 \%$ of total meat production and eggs represent important food for meeting the nutritional status particularly of the vulnerable populations of the children and pregnant woman (Orunlola and Olofinsawe, 2007).

\section{RESEARCH PROBLEM}

The confidence of poultry farmers has been eroded in sound health because they have suffered considerable economic issues due to the failure of vaccination programmes and lack of adequate facility to control and promote poultry production (Torimiro, Lawal and Agbelemege, 2002). Ojo (2003) opined that poultry farmers problems includes high cost of drugs and equipment such as battery cages, de-bakers and incubators, high cost of feeding ingredients, disease cost of medications, marketing and lack of storage facilities as well as unfriendly government policy and finance. It is evident that infrastructure for poultry production has been neglected in Nigeria over a long time. According to Olojede, Adekunle and Samuel (2013), this has negatively affected the poultry farmers and poultry production. For instance, lack of credits and inputs impedes poultry production thereby making farmers to have limited or no access to these facilities. This can cuts small-scale farmers off as their output and income may become lower and lower year after year. This, among other reasons informed the creation of Agricultural Development Programmes in the rural areas in Nigeria. However, the extent of ADP assistance on poultry production has not been done, therefore the study intends to fill this gap in knowledge.

\section{OBJECTIVES}

The main objective of this study is to assess the extent of ADP assistance on poultry production in Ndokwa West Local Government Area, Delta State, Nigeria. Specifically the study intends to:

\section{i. Identify the background information of the poultry farmers \\ ii. Identify the assistance that ADP has provided for the poultry farmers \\ iii. Ascertain the interval visit of ADP to poultry farmers in the study area}

\section{MATERIALS AND METHODS}

The study was carried out to assess the areas of assistance of Agricultural Development Programme on poultry production in Ndokwa West Local Government Area of Delta State. Delta State is situated at the southern part of Nigeria, and Ndokwa West Local Government Area is one of the 25 local governments of Delta State. Ndokwa Local Government has its headquarter at Utagba-Ogbe i.e kwale and is one of the major oil producing areas of the state. It was created in 1991 when the defunct Ndokwa Local Government Area was split into the present Ndokwa-west, Ndokwa-East, and Ukwane. According to the national population census Ndokwa -West has a population strength of about 149,325 people, male $=79,018$, female 70, 307. And a land mass of 1426 square kilometers. The area comprises of forty-two villages and seven major communities and other rural settlement such as Utagba-Ogbe i.e Kwale, Utagbe-Uno, Abbi, Emu, Ogume and Ontisha Ukwani. As the name implies the peoples are Ukwani and their occupation includes pleasant farming, livestock farming, palm produce, fishing and petty trading. 


\section{DATA COLLECTION}

A simple random sampling technique was employed in the selection of six (6) villages in the study, ten (10) poultry farmers were randomly selected from of the six villages giving a total sampled sized of sixty (60) poultry farmers. Both primary and secondary sources of information were used for the study. The secondary source of information was obtained from relevant textbooks, journals and past studies while the primary source of information was obtained from a structured questionnaire administered to the respondents. Data was presented and analyzed with descriptive statistics such as mean, frequency and percentages.

\section{RESULTS}

Table 1: Demographic characteristics of poultry production in Ndokwa West Local Government Area

\begin{tabular}{|lcc|}
\hline Variable & Frequency & Percentage \\
\hline Sex & & \\
Male & 45 & 75 \\
Female & 15 & 25 \\
Age & & \\
$20-30$ & 7 & 11.6 \\
$31-40$ & 8 & 13.4 \\
$41-50$ & 15 & 25 \\
$51-60$ & 18 & 30 \\
61 - above & 12 & 20 \\
Marital status & & \\
Single & 11 & 18.2 \\
Married & 25 & 41.8 \\
Educational qualification & & \\
No formal education & 36 & 50.0 \\
Primary/secondary & 28 & 38.9 \\
College/Polytechnic/University & 8 & 11.1 \\
System of poultry production & & \\
Intensive & 40 & 66.6 \\
Semi intensive & 15 & 25 \\
Extensive & 5 & 8.4 \\
Source of credit & & 30 \\
ADP & 18 & 36.7 \\
Personal savings & 22 & 13.3 \\
Banks & 8 & 20 \\
Cooperative & 12 & \\
\hline
\end{tabular}

Table I above shows that $75 \%$ of the respondents are male while only $25 \%$ are $t$ female. The table also shows that $30 \%$ of the respondent falls within the age of $51-60$ while $41-50$ are $25 \%$ respectively. The table also shows $31-40$ are $13.40 \%$ while $11.6 \%$ falls within the age bracket of $20-30$ years. This means that most people who are invested in poultry farming business are mostly experience people. The table also shows $41 \%$ of the respondents interviewed are married and $18 \%$ are single. This means that poultry farming business were dominated by married men. Table 1 further shows that $50 \%$ of the respondents had no formal education while the $38.9 \%$ had primary/secondary school education. $11.1 \%$ had one formal education ranging from college of education polytechnic and university respectively. 
Table 2: Types of poultry enterprise

\begin{tabular}{|lcc|}
\hline Type & Frequency & Percentage \\
\hline Types of Poultry Enterprise & & \\
Layers (egg production) & 35 & 58.4 \\
Broiler (meat production) & 10 & 16.6 \\
Layers and broiler & 15 & 25 \\
\hline
\end{tabular}

From table 2 above $58.40 \%$ of the poultry farmers where involved in layers/egg production while $16.6 \%$ are only broiler (meat production and $25 \%$ of the poultry farmer from the respondents are layers and broiler production. Again from table I the types of poultry system of production are intensive $(70 \%)$ and semi - intensive $(30 \%)$. Over $83.4 \%$ of poultry birds are acquired through purchase by the individual poultry farmers $16.6 \%$ are inherited from parents or relatives.

Table 3: Distribution of respondents according to training on improve technology in poultry production

\begin{tabular}{|lcc|}
\hline Training & Frequency & Percentage \\
\hline ADP & 20 & 33.3 \\
Cooperatives & 18 & 30 \\
Institutions/Schools & 20 & 33.3 \\
No training & 2 & 3.3 \\
\hline Total & 60 & 100 \\
\hline
\end{tabular}

The table two above shows that $33.3 \%$ were trained through ADP while $30 \%$ were trained by cooperatives, another $33.3 \%$ through the means of institutions /schools. Those without training were $3.3 \%$. This means that ADP trained only few numbers of the people. This is in agreement with Aworemi, Abdul-Azeez, and Opoola (2011) that because majority of the rural farmers are not exposed to adequate training on improved agricultural technology the youths see farming as suffering and not business.

Table 4: Provision of credits/inputs

\begin{tabular}{|lcc|}
\hline Provision of credits/inputs & Frequency & Percentage \\
ADP & 10 & 16.7 \\
Cooperative & 20 & 33.3 \\
Personal purchase & 30 & 50.0 \\
\hline Total & 60 & 100 \\
\hline
\end{tabular}

The result from table 4 above shows that only $16.7 \%$ of the respondents were provided with credits/inputs while cooperative and personal purchase were $33.3 \%$ and $50 \%$ respectively. This implies that majority of the respondents are not provided with credits/ inputs by the ADP as most of them purchase their inputs by themselves.

Table 5: Distribution of respondents according to the level of improvement in their living standard

\begin{tabular}{|lcc|}
\hline Standard of living & Frequency & Percentage \\
\hline Improved & 20 & 33.3 \\
Not improved & 40 & 66.7 \\
\hline Total & 60 & 100 \\
\hline
\end{tabular}


In table 4 above it was observed that $66.7 \%$ of the total respondents shows that their level of living was not improved while $33.3 \%$ of the total respondents shows that their standard of living was improved. This implies that majority of the respondents standard of living has not been improved. According to Handley, Higgins, Sharma, Bird and Cammack (2009) the standard of living of most of the rural farmers is still very low as majority of them live in poverty. Therefore additional effort should be made by ADP so as to improve the work of the poultry farmers and in order to raise of standard of living of the farmers.

Table 6: Distribution of respondents on ADP visitation to the poultry farmers

\begin{tabular}{|ccc|}
\hline Visitation & Frequency & Percentage \\
\hline Occasionally & 20 & 33.3 \\
Regularly & 15 & 25.0 \\
At interval & 25 & 41.7 \\
\hline Total & 60 & 100 \\
\hline
\end{tabular}

Table 3 above shows that $41.7 \%$ were visited at intervals while $25 \%$ were visits occasionally. $33.3 \%$ of the respondents were visited regularly from the Agricultural development programme. This finding shows that the visit by ADP in the study area was mostly at intervals and occasionally. This is in agreement with Akpobo (2007) that ADP occasionally visits farmers to assess their productions and challenges.

\section{CONCLUSION AND RECOMMENDATIONS}

However, it was observed that in spite of the assistance of ADP in the areas of training, provision of credit and inputs $s$ to the poultry farmers the living standard of majority of the poultry farmers in the study area has not improved. Therefore the following recommendations are made

1. ADP should create more sensitization programmes so that more poultry farmers will benefit.

2. More credits and inputs on poultry production should be made available so that more poultry farmers can access the facilities. Agricultural inputs can be made available to the poultry farmers by government through the ADP at subsidized rate.

3. ADP staff should visit farmers regularly so that they can ascertain farmers' challenges and give assistance to the farmers that will help them improve their poultry production.

4. Poultry farmers should endevour to collaborate with the ADP in order to boost poultry production in the study area

\section{REFERENCES}

Abass, I. M. (2010). Poverty and Rural-Urban Habitats in Nigeria Journal of Sociology, Psychology and Anthropology, 2: 113-136

Akpobo, J.G. (2007). Review of Agricultural Extension Approaches Implemented in Nigeria. Ina Training Manual for Orientation/Refresher Course on Extension Communication Techniques for Extension Workers in the ADPs/LGAs in the North West Zone. Zaria: NAERLS/ABU.

Aworemi, J. R., Abdul-Azeez, I.A \& Opoola, N. A. (2011). An Appraisal of the Factors Influencing Rural-Urban Migratio $\mathrm{n}$ in Some Selected Local Government Areas of Lagos State Nigeria. Journal of Sustainable Development, 4(3): 136-141

Delta State Ministry of Agriculture and Natural Resources, (2011). A Handbook on Delta State Agriculture. Asaba, Delta State

Handley G, Higgins K, Sharma B, Bird K \& Cammack D. (2009). Poverty and Poverty Reduction in Sub-Saharan Africa: An Overview of Key Issues. London: Overseas Development Institute. 
Oladejo, J. A., Olawuyi, S. O and Anjorin, T. D. (2011). Analysis of Women Participation in Agricultural Production in Egbedore LocalGovernment Area of Osun State, Nigeria.International Journal of Agricultural Economics and Rural Development, 4(1): $1-10$

Olojede, A. A., Adekunle, A.A and Samuel, E. A. (2013). Analysis of Rural Literacy as a Panacea for Socio-Economic Development of Nigeria. International Journal of Sociology and Anthropology, 5(9): 381-390,

Ojo S. O ( 2003) productivity and technical efficiency of poultry egg production in Nigeria. International journal of poultry science $2.459-464$

Okowea S. E ( 2007). The need for a dynamic and effective Agricultural Development policy for east central states work for publication Enugu pg up

Orunlola, J. O and Olofinsawe, A (2007). Effect of extension activities on poultry production in Ondo state south western Nigeria. Agricultural $2559-563$

Torimiro, D. O. Lawal, B. O \& Agbelemege, A. (2002) comparative study of cooperative and non comparative poultry farmers in Ijebu Division of Ogun state, Nigeria. Nigeria journal of rural sociology $3.33-42$

This is an open-access article published and distributed under the terms and conditions of the $(\mathrm{cc}) \mathrm{EY}$ Creative Commons Attribution 4.0 International License of United States unless otherwise stated. Access, citation and distribution of this article is allowed with full recognition of the authors and the source.

Authors seeking to publish with an International Peer Reviewed Journal should consider www.ijcab.org by writing to the Editor at editor@ijcab.org. List of our Journals are Available at www.ijcab.org/journals 